\title{
Internal Financial Risk Management In Microfinance Companies: A Case Study Of Akuapem Rural Bank, Ghana
}

\author{
Rebecca Davis ${ }^{1}$, Elvis K. Donkoh ${ }^{2}$, Bernard Mawah ${ }^{3}$, Blessed Amonoo ${ }^{4}$ \\ ${ }^{1,4}$ Department of Mathematical \& Actuarial Science, Box KN1739, Accra, Ghana Pentecost University College, Ghana. \\ 2 School of Sciences, Department of Mathematics \& Statistics, University of Energy \& Natural Resources, Sunyani, \\ Ghana. \\ ${ }^{3}$ Department of Accounting \& Finance, Pentecost University College, Box KN1739, Accra, Ghana \\ Correspondence: Elvis K. Donkoh, Department of Mathematics \& Statistics, University of Energy \& Natural Resources, \\ Sunyani, Ghana, Box 214, Sunyani. Tel: +233507452075. E-mail: elvis.donkor@uenr.edu.gh
}

Received: May 3, 2018 Accepted: May 18, 2018 Online Published: August 9, 2018

doi:10.5539/ijsp.v7n5p64

URL: https://doi.org/10.5539/ijsp.v7n5p64

\begin{abstract}
The operations of Microfinance Institutions (MFIs) in Ghana have recently come under serious public scrutiny. This position was fairly caused by Bank of Ghana's (BOG's) announcement regarding 70 microfinance companies whose provisional licenses were revoked BOG (2016). This led to the closure of DKM Diamond Microfinance and some other microfinance companies in the country. This worsening circumstance surrounding the microfinance industry calls for the need to provide practical knowledge on the use of financial analysis tools to manage internal financial risks of the microfinance industry. Data from Akuapem Rural Bank (AKRB) financial statements for the period of 2008 to 2015 (refer to appendix) was analysed using regression analysis, descriptive statistics, trend analysis and ratios. It was observed that the profitability of AKRB is greatly influenced by credit risks, bank size, interest income growth and debt-ratio. The study also revealed that AKRB had comprehensive and adequate risk management structures in place in managing its credit and other operational risks.
\end{abstract}

Keywords: financial analysis, internal financial risks, profitability, microfinance, risk management, risks

\section{Introduction}

Karlan and Goldberg (2007) put it that microfinance is the provision of small-scale financial services to people who lack access to traditional banking services. More broadly, microfinance refers to a movement that envisions a world in which low-income households have permanent access to a range of high quality and affordable financial services offered by a range of retail providers to finance income-producing activities, build assets, stabilize consumption, and protect against risks (Yunus,2012). Risks are inevitable in the financial markets of every economy around the world. The occurrence of risks in finance poses a lot of threats to the profitability and sustainability of financial institutions. Risk management cut across every sector of the economy of which the financial sector is not of an exception. Risk management is the process of identification, analysis and acceptance or mitigation of uncertainty in investment and other financial decisions. This calls for the appropriate action or (inaction) to be taken given the corporate entity's objectives and risk tolerance level.

Any financial institution which collects customers deposits in a form of savings or otherwise would always like to make profit by putting them in an investment. This is to help the institution to pay some competitive interest to its customers as and when it demands. The institution then decides to create a credit facility with these deposits with the hope of making profit. This business venture is characterized with uncertainty since a borrower may default in paying back the loan. Moreover economic events may also be a determinant thus there is a risk attached that has to be managed effectively to mitigate any potential losses.

Microfinance companies also struggle in their attempt to manage their internal financial risks as experienced by the other banks. Most of these Microfinance companies lack the technocrats, resources and technology needed to effectively identify, analyse, evaluate and mitigate financial risks effectively. So most of them end up collapsing or are caught in poor financial risk management practices.

This tends to have adverse effects on the profitability and sustainability of these companies.

According to Boateng (2016), microfinance in Ghana is characterized by high risks, with unethical and illegal practices, mismanagement and disregard of due diligence, which when convoluted by external factors like macroeconomic 
instabilities and panic withdrawals, pushed the risk levels of MFI's beyond the point of containment. They are mostly located in the rural areas, parts of urban areas and other remote parts of the country. They mostly deal with petty traders, illiterate people, clients who don't have regular flow of income to offset loans repayments and small-scale business. This makes this venture riskier as compared to the traditional banking sector of the economy. Notwithstanding, Ghana's microfinance sector is contributing to improving livelihoods of their targeted clients and their local economy in general. This calls for the need of a workable approach to solve the problem confronting the sector in the short to long term.

\section{Related Works}

Risks management is vital for every firms operations in Microfinance.This is done by either scrutinizing the aggregation of risks or to build up their exposures from individual risks which are both useful in today's practice.. Financial risk management is the activity of monitoring financial risks and managing their impact. It draws on the disciplines of accountancy, economics, management science, decision theory, statistics and psychology as well as the key principles and methodologies to be found in finance. According to Moles (2013), sensitivity is a key concept in risk management. Knowing the degree of responsiveness to the source of risk is essential in order to manage the risk.

In an economy, risk can be managed by either modifying the level or by risk transfer. At the aggregate level the total amount of risk in the economy cannot be reduced, but its economic consequences can be modified through sharing its consequences or transferring the risk to another party. Sharing of risks have the effect of spreading among all market participants. For example, in insurance, losses are shared among the pool of insured parties. Risk transfer involves reassigning the risk to another party for a fee. For instance, many industrial and commercial firms transfer their foreign exchange exposures to banks by buying forward foreign exchange contracts. The bank then manages the resultant risks.

The financial risk management activities and process is complex with three approaches including hedging, diversification and insurance. Hedging leads to the elimination of risk through its sale in the market, either through cash or spot market transactions or through a transaction, such as a forward, future or swap, that represents an agreement to sell the risk in the future. Diversification reduces risk by combining less than perfectly correlated risks into portfolios. For instance, while individual borrows from a bank, each represent a significant element of credit risk, for the depositors at the average bank there are virtually no concerns about credit risk. Insurance involves paying a fee to limit risk in exchange for a premium. For example, one has only to consider the benefits to be derived from paying a fixed premium to protect against property damage or loss, or for life assurance, in the traditional insurance contract. In doing so, the insurer, usually an insurance company, takes on the risk of unknown future losses.

Individuals and organisations can manage risks by increasing shareholder value. For individuals it may be their wealth, or 'utility'. In essence, organizations will be evaluating risk on the basis of cost-benefit criteria. The cost of risk management relates to the price to be paid for risk control, be it via insurance, management time or lost opportunities from hedging. Firms will want to economise on these incidental expenses of being in business.

The internal risk management process include

i. Finding the source of the risk exposure.

ii. Measure and evaluate the exposure to risks.

iii. Assess the impact of the exposure on the firm's business and financial strategy. Determine the degree of risk adjustment required against predetermined criteria. This often takes the form of a cost-benefit analysis.

iv. Assess the firm's capabilities, competencies and/or capacity to undertake its own hedging and insurance programme.

v. Select the appropriate risk management product and mix. This will typically include both operational hedging and the use of external risk management products such as insurance contracts, derivatives and risk pooling.

vi. Reviewing risk management process.

vii. Cited by Bauman et al. (1994) financial risk exposure can be applied in practice by providing a logical series of steps, together with the required analysis, policy formulation and operational procedures that are required in order to properly manage and control the ongoing risks in the firm. 


\section{Methodology}

Regression analysis with charts, tables and descriptive statistics was used to analyse the data. Profitability model together with ratio analysis were also employed in the analysis. A mathematical model was used to assess the profitability of AKRB and the ratio analysis to analyse trends and relationships of financial statements items. The Basic model used for the study to determine profitability is

$$
R O E_{i, t}=\alpha_{0}+\beta \text { Size }_{i, t}+\gamma I M T L A_{i, t}+\mu \operatorname{Growth}_{i, t}+\rho P P P N T L A_{i, t}+\sigma T D A_{i, t}+\tau C L G L_{i, t}+\varepsilon_{i, t}
$$

Where

ROE - Profitability $=$ Return on Equity (Net Income to Total Equity Fund) of Bank $i$ in time $t$

SIZE - Bank Size $=$ the log of Total Assets of Bank $i$ in time $t$

IMTLA - Credit risks $=$ impairments/ Total Loans and Advances of bank $i$ in time $t$

GROWTH - Growth in Bank's interest income, year on year

PPPNTLA - Credit Risk $=$ Pre-Provision Profit/Net Total Loans and Advances of bank $i$ in time $t$

TDA - Leverage $=$ the ratio of Total Debt to Total Net Assets for Bank $\mathrm{i}$ in time t. a measure for bank capital structure

CLGL - Credit risk $=$ the ratio of Customer Loans to Gross Loans and Advances of bank $i$ in time $t$

E - The error term

The dependent variable in model (1) is Return on Equity while the explanatory variable is credit risk which is measured by three main variables, that is ratio of Impairments to Total Loans and Advances, ratio of Customer Loans to Gross Loans and Advances and ratio of Pre-Provision Profit to Total Loans and Advances. The effects of other factors such as bank size, bank growth rate and the choice of capital structure in the firms profitability was controlled. The response variable employed in the study is return on equity (ROE).

\subsection{Descriptive Statistics of Model Variables}

Table 3.1 gives information about the descriptive statistics of the response, the independent and the control variables. The average (standard deviation) performance of the bank was 0.2796 (0.11550). This shows that equity shareholders were able to generate a return of $27.96 \%$ which can be considered as fairly good and also the payback period is approximately about 3 years. The minimum recorded profitability was as low as $2.6 \%$ while the maximum was about $40.3 \%$. Also, Impairments to Total Loans and Advances averaged (standard deviation) at 2.85\% (0.02851). Impairments data for 2008-2012 were not available to be included in the analysis. This results on impairment to total loans and advances can be considered as low since the on the average the proportion of loans impaired is about $3 \%$ of total loans and advances. This is as a result of the quality loans given out by the bank and good policies framework governing its credit facilities. The ratio of customer loans to gross loans and advances was astonishing. As high as $70.48 \%$ of gross loans and advances was considered to be customer loans. This depicts that AKRB's customer loans constituted higher proportion of its gross loans and advances portfolio. This further suggest that AKRB credit facility is mostly patronised by its customers and thus reducing its credit risk since these customers can easily be traced in case of default by using their information at its disposal. Again, pre-provision profits to total loans and advances had a mean (standard deviation) of 16.87\% (0.060689). Firm size (log of total assets) was $16.80 \%$ while the average (standard deviation) growth rate was $28.87 \%(0.2228)$. This shows a less significant growth in the bank.

The ratio of total debt to net total assets was $82.65 \%(0.028215)$ thus debt capital represents a greater proportion of bank total capital. This confirms the generalised view that banks are highly leveraged together with its low standard deviation.

Table 3.1. Descriptive Statistics

\begin{tabular}{llllll}
\hline Var. & Obs. & Mean & Std. Dev. & Min & Max \\
\hline ROE & 8 & 0.27963 & 0.11550 & 0.026 & 0.403 \\
\hline Size & 8 & 16.79638 & 0.51729 & 15.96671 & 17.2996 \\
\hline IMTLA & 8 & 0.01968 & 0.02851 & 0.00000 & 0.15743 \\
\hline Growth & 8 & 0.28865 & 0.22277 & 0.00000 & 0.75618 \\
\hline PPPNTLA & 8 & 0.16866 & 0.060689 & 0.080296 & 0.24886 \\
\hline TDA & 8 & 0.82652 & 0.028215 & 0.79294 & 0.87059 \\
\hline CLGL & 8 & 0.704803 & 0.435335 & 0.00000 & 0.96081 \\
\hline
\end{tabular}




\section{Regression Analysis of Model Results}

Table $4.1 \& 4.2$ present the regression results of the analysis. Variables such as Size, Growth and IMTLA had negative coefficients whilst TDA, PPPNTLA and CLGL all emerged positive from the multiple regression results. The study shows that credit risk, size of a bank, bank growth rate and capital structure are the key factors which influence the profitability of AKRB. From the analysis, it was revealed that the bank size has negative effects on AKRB's profitability holding the other variables constant. This suggest that as the ln of bank's asset increases by $e=2.718$ it reduces the performance of the bank by $40 \%$ on average. That is the bank's asset increase does not contribute much to its performance. Also, credit risk such as IMTLA, PPPNTLA and CLGL had significant effect on the performance of the bank. With the exception of IMTLA the rest were revealed to have positive impact on the bank's performance. IMTLA coefficient was -3.54956, thus all other things being equal holding the other variables constant as ratio of impairments to total loans and advances increases by 1 it reduces the bank's profitability by $354.956 \%$. This is true since increase in impairment charges (provision for bad and doubtful debts) reduces the net income of banks. This consequently affects their performance, thus lower returns of shareholders investments in the firm. PPPNTLA and CLGL happened to have positive impact on the performance of AKRB. PPPNTLA happened to increase profitability by $699.32 \%$ as PPPNTLA increases by 1 whilst holding the other variables constant. This is true since PPPNTLA calculation on the income statement don't take into effect bad and doubtful debts because most loans span more than a year before default. So when this profit is used eventually it will increase returns on shareholders' equity. Also, CLGL which is customer loans to gross loans and advances had positive impact on the bank's performance. CLGL is calculated to know the proportion of a bank's customer loans to its gross loans and advances. This helped in credit risk management, thus a bank whose customer loan constitutes higher percentage of its gross loans and advances will be at a safer side and vice-versa. Because most customers loans payments are deducted from their deposits account with bank, so this make the bank more secure in relating to dealing with the customer. CLGL had a positive and significant increase of $48.87 \%$ as the ratio of customer loans to gross loans and advances increases by 1 on profitability of AKRB whilst the other variables are held constant.

The bank's growth rate had a negative impact on its performance from the analysis. It was revealed that as the assets increases by 1 the bank's growth reduces its profitability by $38.63 \%$. Also, the capital structure of the Bank had positive and significant increase on the bank's profitability. From the analysis TDA increased profitability by $631.1 \%$ as debt ratio increases by 1 holding the other variables constant. Thus an increase in the debt ratio of AKRB eventually increases its profitability by that margin. The tables below provide the details of the results.

Table 4.1 Regression Results of the Analysis

\begin{tabular}{llll}
\hline & \multicolumn{3}{l}{ Multiple Regression Results } \\
\cline { 2 - 4 } Var. & Coefficient & $t$-test, $\quad \alpha=5 \%$ & Prob. \\
\hline Size & -0.40377 & -2.87297 & 0.21324 \\
\hline (IMTLA) & -3.54956 & -1.52804 & 0.36891 \\
\hline Growth & -0.38630 & -2.01371 & 0.29343 \\
\hline PPPNTLA & 6.99322 & 4.83219 & 0.12991 \\
\hline TDA & 6.31056 & 4.59976 & 0.13628 \\
\hline CLGL & 0.48866 & 3.17032 & 0.19452 \\
\hline
\end{tabular}

Table 4.2 Correlation Results

\begin{tabular}{lr}
\hline \multicolumn{2}{c}{ Regression Statistics } \\
\hline Multiple R & 0.992796445 \\
\hline R Square & 0.9856447781 \\
\hline Adjusted R Square & 0.899513466 \\
\hline Standard Error & 0.036612683 \\
\hline Observations & 8 \\
\hline
\end{tabular}




\subsection{Credit Risk}

The risk areas have to do with larger exposures, diversification, and concentration and over exposure to an economic sector. In the year 2014 the bank was able to minimize the volume of exposure concentration on its twenty largest customers as against that in 2015. In the year 2015 AKRB largest exposures was $25.01 \%$ as against $16.09 \%$ in the year 2014. This maximized the risk that the microfinance carried on its loan book in the consequent year. However, the percentage of non-performing loans to gross loans and advances in the year 2015 was $9.96 \%$ as against $15.07 \%$ in the year 2014. This signify that the rural bank credit administration and loan monitoring had become stronger in the year 2015 . Also, AKRB recorded a lower Loans Loss Provision Ratio in the year 2015 as $5.01 \%$ as against $6.97 \%$ in the year 2014 . This signifies that the improvement in the ratio of Non- Performing Loans to Gross loans and advances has positively affected the performance of Loans Loss Provision ratio in the consequent year. This is shown in Table 4.3

Table 4.3. Useful ratios that measure the loan portfolio performance of AKRB

\begin{tabular}{lll}
\hline & 2015 & 2014 \\
\hline Loans Loss Provision Ratio & $5.01 \%$ & $6.97 \%$ \\
\hline Gross Non-Performing Loans Ratio & $9.96 \%$ & $15.07 \%$ \\
\hline 20 Largest Exposures & $25.01 \%$ & $16.09 \%$ \\
\hline
\end{tabular}

\subsection{Loans Distribution}

The bank continued its trend of granting loans to individuals as compared to private enterprises, public enterprises and institutions and other potential customers. In the year 2010 78.12\% of AKRB loans were given to individuals, this percentage was increased in the year 2011 to $83.09 \%$ which also happen to be the highest so far over the years in percentage wise not in volume of amount given out as loans to individuals. The percentage of loans given to individuals continued to fluctuate slightly over the years, as at the year 2015 the percentage of loans given to individuals by the bank was $70.68 \%$. Table 4.4 provides the detail

Table 4.4. Percentage of Loans disbursed to the Various Customers of AKRB

\begin{tabular}{lrrrrrr}
\hline TYPE OF CUSTOMER & 2010 & 2011 & 2012 & 2013 & 2014 & 2015 \\
\hline Individuals & $78.12 \%$ & $83.09 \%$ & $67.78 \%$ & $66.58 \%$ & $68.00 \%$ & $70.68 \%$ \\
\hline Private Enterprises & $3.72 \%$ & $1.63 \%$ & $1.68 \%$ & $7.09 \%$ & $5.51 \%$ & $3.91 \%$ \\
\hline Public Enterprises \& Institutions & $1.51 \%$ & $1.90 \%$ & $7.64 \%$ & $4.37 \%$ & $2.21 \%$ & $1.08 \%$ \\
\hline Others & $16.65 \%$ & $13.39 \%$ & $22.90 \%$ & $21.96 \%$ & $24.28 \%$ & $24.33 \%$ \\
\hline Total & $100.00 \%$ & $100.00 \%$ & $100.00 \%$ & $100.00 \%$ & $100.00 \%$ & $100.00 \%$
\end{tabular}

The trend of loans giving to customers from 2010 to 2015

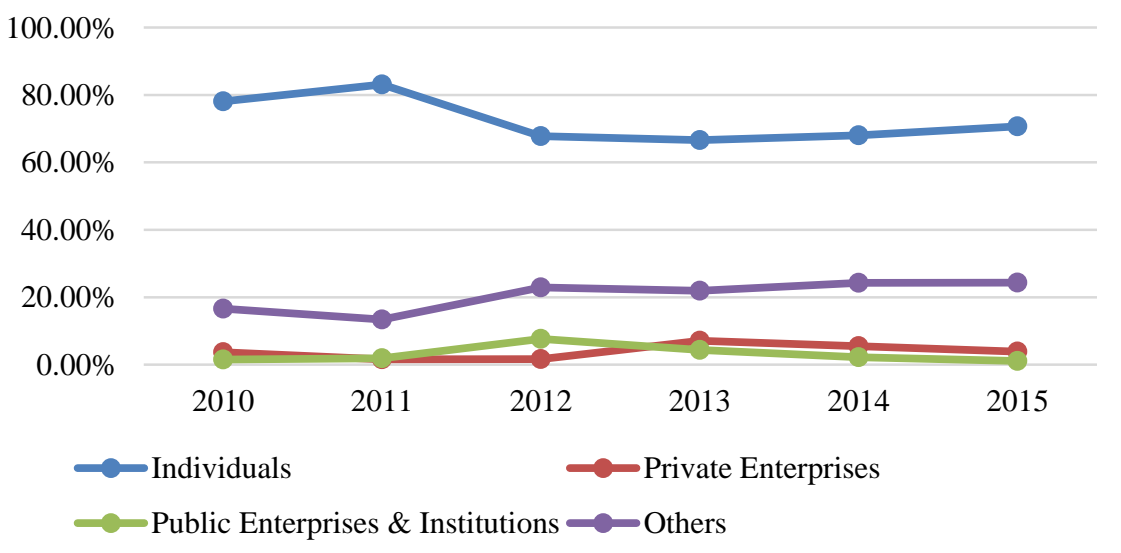

Figure 4.5 Growth of Customer Loans disbursement from 2010-2015 


\subsection{Liquidity Risks}

Liquidity risk is the risk that the bank will encounter difficulty in meeting obligations associated with financial liabilities that are settled by delivering cash or another financial asset. Liquidity risk is to be managed by continue review of future commitments and credit facilities. Table 4.5 shows the some useful ratios to assess the liquidity risk position of the microfinance from 2008 to 2015 with a graphical view in Figure 4.6. The percentage of Customer loans to Customer deposits fluctuated over the years. In 2008 the percentage of Customer loans to Customer deposits was $56.41 \%$ it rose to $59.23 \%$ in 2009 and kept falling to as low as $38.13 \%$ in 2015. The fall in the percentage of Customer loans to Customer deposits is due to rapid increase in the volume of customer deposits over the years as compare to the steady growth of the customer loans during the period. The volumes of loans and advances given by AKRB increased over the years but it growth was slow this may be as a result of the economic hardships faced by the country during the period of study thus discouraging people from borrowing due to its associated costs.

Also, the ratio of AKRB short-term investments (readily marketable assets) fluctuated over the years. In 2008 the percentage of readily marketable assets to total assets was $31.70 \%$ it fell to $17.49 \%$ in 2011 . This percentage in 2011 increased significantly over years to $33.09 \%$ in 2015 . There was also a slight fluctuation in the liability dependency ratio over the period of the study. The ratio of liquid assets to volatile(liquid) liabilities was 0.619 in 2008 it increased to 0.701 in 2009 and continue to fall as low as 0.547 in 2011 . The liability dependency ratio then increased to 0.861 in 2015 which signified a significant increase after the fall in 2010. The composition of volatile liability to total liability was very high despite slight fluctuations over the period of the study. The composition of volatile liability to total liability in 2008 was $84.6 \%$, there was a shortfall in the periods of 2009 and 2010 but it later recovered in 2012 with a percentage of $90.6 \%$. As at 2015 the composition of volatile liability of AKRB to its assets has increased to $94.50 \%$.

Table 4.5 Major liquidity ratios of AKRB for 2008-2015

\begin{tabular}{lcccc}
\hline Years & $\begin{array}{l}\text { Customer Loans/ } \\
\text { Customer } \\
\text { Deposits }\end{array}$ & $\begin{array}{l}\text { Readily Marketable } \\
\text { Assets/ Total Assets }\end{array}$ & $\begin{array}{l}\text { Liquid assets/ } \\
\text { volatile Liabilities }\end{array}$ & $\begin{array}{l}\text { Volatile Liabilities / } \\
\text { Total liabilities }\end{array}$ \\
\hline 2008 & 0.564 & 0.317 & 0.619 & 0.846 \\
\hline 2009 & 0.592 & 0.315 & 0.701 & 0.823 \\
\hline 2010 & 0.577 & 0.185 & 0.560 & 0.874 \\
\hline 2011 & 0.562 & 0.175 & 0.547 & 0.886 \\
\hline 2012 & 0.480 & 0.270 & 0.617 & 0.906 \\
\hline 2013 & 0.500 & 0.302 & 0.661 & 0.887 \\
\hline 2014 & 0.444 & 0.315 & 0.744 & 0.936 \\
\hline 2015 & 0.381 & 0.331 & 0.861 & 0.945 \\
\hline
\end{tabular}


Trends of some useful liquidity ratios over the period 2008 to 2015

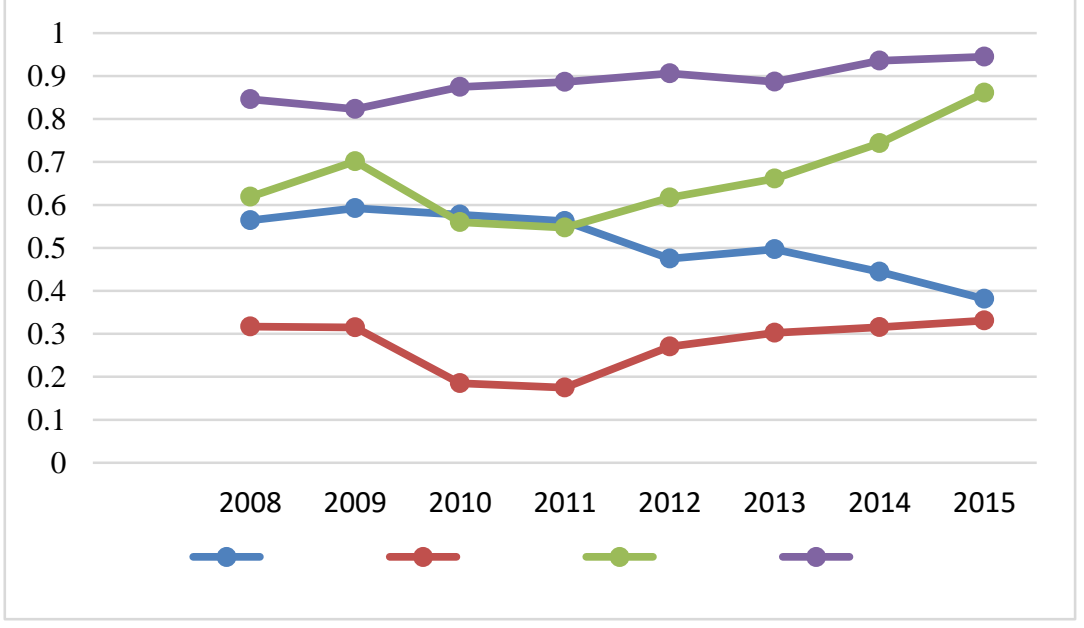

Figure 4.6:Trend of some liquidity ratio's from 2008 - 2015

\subsection{Interest Rate Risk}

In the year 2014 the competitive nature of the industry also compelled the bank to reduce its lending rate to its customers so as to maintain doing business with them. In the course of the year 2014 the policy rate changed by 500 basis points from $16 \%$ to $21 \%$. And with respect to this increase the bank still was compelled not to increase its lending rate due to the competitive pressure among the banks. In the year 2015 the prime rate saw an increase from $21 \%$ in 2014 to $26 \%$. The inflation rate also went up marginally from $17.0 \%$ to $17.7 \%$ in the year 2015, this made the cedi depreciated against all the major trading currencies throughout the year 2015.

\subsection{Efficiency}

Efficiency measures the capacity of the microfinance to generate income at a low cost or by minimizing operating expenses. Thus it measures the proportion of expenses or income that are spent or made in using its assets. The ratios of Net Interest Income to Total Assets over the years were slightly unstable. In 2008, the ratio of Net Interest Income to Total Assets was 0.132. This ratio improved over the years with a slight fluctuation. In 2014 the ratio of Net Interest Income to Total Assets has appreciated to 0.199 but it fell to 0.191 at the end of the 2015 .

The ratio of Net Interest Income to Gross Loans and Advances also saw a steady growth over the years. The ratio of Net Interest Income to Gross Loans and Advances in 2008 was 0.329 . This ratio increased steadily but significant over the years to 0.634 in 2015 which also happen to be the highest ratio. There has been unstable growth in the ratios of Operating Expenses to Total Assets over the period. Over the period of 2008, a ratio of 0.119 was recorded as compared to a ratio of 0.161 in 2010 . These ratios kept on fluctuating, as at 2015 the ratio has fallen to 0.146 as compared to 0.154 recorded in 2014. This is shown in Table 4.6.

Table 4.6. Efficiency Ratios of AKRB over the period 2008-2015

\begin{tabular}{ccccc}
\hline Years & $\begin{array}{l}\text { Net Interest Income / } \\
\text { Average total Assets }\end{array}$ & $\begin{array}{l}\text { Net Interest Income / } \\
\text { Gross Loans and } \\
\text { Advances }\end{array}$ & $\begin{array}{l}\text { Operating } \\
\text { Expenses / Average } \\
\text { total Assets }\end{array}$ & $\begin{array}{l}\text { Operating Expenses } \\
\text { / Gross Operating } \\
\text { Income }\end{array}$ \\
\hline 2008 & 0.132 & 0.329 & 0.119 & 0.692 \\
\hline 2009 & 0.179 & 0.462 & 0.119 & 0.554 \\
\hline 2010 & 0.182 & 0.442 & 0.161 & 0.756 \\
\hline 2011 & 0.155 & 0.354 & 0.154 & 0.154 \\
\hline 2012 & 0.158 & 0.394 & 0.140 & 0.750 \\
\hline 2013 & 0.183 & 0.452 & 0.136 & 0.654 \\
\hline 2014 & 0.199 & 0.545 & 0.154 & 0.679 \\
\hline 2015 & 0.191 & 0.634 & 0.146 & 0.692 \\
\hline
\end{tabular}




\section{Conclusion}

The results from the analysis of the liquidity risks of AKRB was not all that satisfactory. It was found out in the analysis that the average percentage of liquid assets to volatile liabilities was $60 \%$. Thus an average of $60 \%$ of volatile (liquid) liabilities can be covered given AKRB corresponding liquid assets. The results of the analysis also revealed that percentage of volatile liabilities to total liabilities was averagely $82 \%$, thus most of its liabilities are current and this called for provision of adequate liquid assets to help meet such obligations when they arise.

Lastly, the study revealed that credit risk, size of a bank, bank growth rate and capital structure are the key factors which influence the profitability of AKRB.

\section{References}

Bauman, J., Saratore, S., \& Liddle, W. (1994). A Practical Framework for Corporate Exposure Management. Journal of Applied Corporate Finance, 7(3), 66-72.

Bernstein, P. L. (1996). Against the Gods: The Remarkable Story of Risk. New York: John Wiley \& Sons.

Black, F., \& Scholes, M. (1972). The Valuation of Option Contracts and a Test of Market Efficiency. Journal of Finance, 399-418.

Black, F., \& Scholes, M. (1973). The Pricing of Options and Corporate Liabilities. Journal of Political Economy, 81, (May-June), 637-54.

Boateng, F. G., Nortey, S., Asamanin, B. J., Dwumah, P., Acheampong., M., \& Ackom-Sampene, E. (2016). Collapsing Microfinance Institutions in Ghana: An Account of How Four Expanded and Imploded in the Ashanti Region. International Journal of African Development, 3(2).

BOG. (2016, April 14). Retrieved May 12, 2017, from Bank of Ghana: https://www.bog.gov.gh/supervision-a-regulation/register-of-licensed-institutions/provisional-register-of-licensed rural-and-community-banks

Casserley, D. (1993). Facing up to the Risks. New York: John Wiley \& Sons.

Karlan, D., \& Goldberg, N. (2007). The Impact of Microfinance: A Review of Methodological Issues. The World Bank. November.

Moles P. (2013). Financial Risk Management Sources of Financial Risk and Risk Assessment. Edinburgh Business School Heriot-Watt University, UK.

Ottens, D., Lambregts, E., \& Poelhekke, S. (2005).Credit Booms in Emerging Market Economies: A Recipe for Banking Crises. Working paper No. 046/2005, (pp 1-16). De Nederlandsche Bank NV, Amsterdam.

Yunus M. (2012). International Centre for Microfinance and Social Business. Turkey. http://muhammedyunus.okan.edu.tr/what-is-microfinance.php 


\section{Appendix}

Assets and Liabilities of AKRB and RCB's from 2013 - 2015.

Table A.1 Common Size Ratios of AKRB and RCBs for 2013-2015

Akuapem Rural Bank Industry Consolidated Financial Statement Ratio

\begin{tabular}{|c|c|c|c|c|c|c|}
\hline Years & 2013 & 2014 & 2015 & 2013 & 2014 & 2015 \\
\hline \multicolumn{7}{|l|}{$\underline{\text { Assets }}$} \\
\hline $\begin{array}{l}\text { Cash Holdings \& Balances with } \\
\text { Banks }\end{array}$ & $9.31 \%$ & $8.37 \%$ & $6.76 \%$ & $14.55 \%$ & $14.95 \%$ & $14.70 \%$ \\
\hline Bills \& Bonds & $40.09 \%$ & $47.34 \%$ & $57.37 \%$ & $28.83 \%$ & $30.74 \%$ & $30.79 \%$ \\
\hline Loans \& Advances & $37.11 \%$ & $33.59 \%$ & $28.58 \%$ & $38.77 \%$ & $37.44 \%$ & $37.11 \%$ \\
\hline Other Assets & $13.49 \%$ & $10.70 \%$ & $7.30 \%$ & $17.85 \%$ & $16.86 \%$ & $17.40 \%$ \\
\hline Total Assets & $\begin{array}{r}100.00 \\
\%\end{array}$ & $\begin{array}{r}100.00 \\
\%\end{array}$ & $\begin{array}{r}100.00 \\
\%\end{array}$ & $100.00 \%$ & $100.00 \%$ & $100.00 \%$ \\
\hline
\end{tabular}

\begin{tabular}{|c|c|c|c|c|c|c|}
\hline$\underline{\text { Liabilities }}$ & & & & & & \\
\hline Total Deposits & $74.72 \%$ & $75.56 \%$ & $74.93 \%$ & $74.06 \%$ & $76.61 \%$ & $76.33 \%$ \\
\hline Shareholder's Funds & $15.74 \%$ & $19.23 \%$ & $20.71 \%$ & $13.31 \%$ & $13.48 \%$ & $13.65 \%$ \\
\hline Other Liabilities & $9.54 \%$ & $5.21 \%$ & $4.36 \%$ & $12.62 \%$ & $9.91 \%$ & $10.01 \%$ \\
\hline Total Liabilities & $\begin{array}{r}100.00 \\
\%\end{array}$ & $\begin{array}{r}100.00 \\
\%\end{array}$ & $\begin{array}{r}100.00 \\
\%\end{array}$ & $100.00 \%$ & $100.00 \%$ & $100.00 \%$ \\
\hline
\end{tabular}

\section{Copyrights}

Copyright for this article is retained by the author(s), with first publication rights granted to the journal.

This is an open-access article distributed under the terms and conditions of the Creative Commons Attribution license (http://creativecommons.org/licenses/by/4.0/). 